УДК 664.8.047

Снєжкін Ю.Ф., Муляр В.П., Дабіжа Н.О.

Інститут технічної теплофізики НАН України, м. Київ

\title{
АНАЛІЗ СУЧАСНИХ СПОСОБІВ СУШІННЯ ТА РОЗРОБКА ОПТИМАЛЬНОГО РЕЖИМУ СУШІННЯ КОЛОЇДНИХ КАПІЛЯРНО-ПОРИСТИХ МАТЕРІАЛІВ У ТЕПЛОНАСОСНІЙ СУШАРЦІ 3 КОМБІНОВАНИМ ТЕПЛОПІДВОДОМ
}

Наведені основні способи сушіння колоїдних капілярно-пористих матеріалів та установки, в яких вони реалізуються; представлено шляхи оптимізації процесу сушіння у теплонасосній сушариі шляхом застосування комбінованого теплопідводу.

Приведены основные способы сушки коллоидных капиллярно-пористых материалов и установки, в которых они реализуются; представлены пути оптимизации сушки в теплонасосной сушилке путем применения комбинированного теплоподвода.

The basic drying methods of colloidal capillary-porous materials and settings for they implementation were analyzed. The ways of optimization of drying process in a dryer by using heat pump with combined heat supply are presented.

\section{Постановка проблеми}

Враховуючи загальну тенденцію енергоспоживання, яка веде до збільшення кількості спожитої енергії в усьому світі, вартість цієї енергії безперервно підвищується, та зростає іï дефіцит. Тому гостро стоять проблеми створення та широкомасштабного впровадження сучасних енергоефективних теплотехнологій, які забезпечують скорочення витрат енергоносіїв.

Одним із енергоємних процесів, що застосовується в багатьох галузях промисловості, є сушіння. Так, на процеси термічного зневоднення в світі витрачається біля 10\% всієї енергії. Тому питанню енергозбереження в сушильній техніці в останній час приділяють значну увагу.

Процеси сушіння широко застосовують у промисловості для зневоднення різноманітних вологих матеріалів на різних стадіях їх переробки. Вологу з матеріалів можна видалити різними способами: механічним, фізико-хімічним і тепловим, який є найбільш розповсюдженим. При тепловому способі волога випаровується 3 поверхні матеріалу і дифундує в навколишнє повітря, яке виносить вологу із сушарки. Із цього 
випливає, що сушінням називають термічний процес видалення вологи 3 матеріалів внаслідок її випаровування і дифузії.

Одним $з$ таких матеріалів є керамічні вироби, в технології виготовлення яких сушіння є відповідальним етапом. Під час сушіння в керамічних виробах виникають тріщини, які виявляються при відпалі, що значно знижує якість готового продукту. Зазвичай при виготовленні керамічних виробів матеріал висушують до залишкового вологовмісту $8-12 \%$.

Метою дослідження є аналіз сучасних способів сушіння та розробка оптимальних режимів теплонасосного сушіння колоїдних капілярно-пористих матеріалів (ККП) із комбінованим теплопідводом.

\section{Викладення основного матеріалу}

Методи сушіння вологих матеріалів розрізняються переважно способом підведення теплоти. Вибір методу також зумовлений фізико-хімічними властивостями цих матеріалів. Найпоширенішим є метод конвективного сушіння, що характеризується безпосереднім контактом матеріалу з потоком нагрітого газу (повітря, димових газів). Волога випаровується за допомогою теплоти нагрітого газу, який одночасно поглинає i виносить із сушарки утворену водяну пару.

ККП матеріали, до яких відносяться і керамічні вироби, піддаються сушінню в камерних, тунельних конвеєрних та інших сушарках. Також існують комбіновані методи сушіння із застосуванням додаткових джерел енергії (розглянемо їх далі). Сушіння колоїдних капілярно-пористих матеріалів часто реалізовується в конвективних сушарках із застосуванням теплових насосів [1].

Цикл сушіння в конденсаційних теплонасосних сушарках (рис. 1) здійснюється таким чином: нагріте і осушене повітря (стан $a$ ) надходить до сушильної камери 1, де, проходячи над шаром висушуваного матеріалу, адіабатично зволожується i його температура знижується (стан $a-b$ ). Зволожене повітря осушується у випарнику теплового насоса 2 за рахунок охолодження (процес $b-c-d$ ) до заданої температури точки роси (стан $d$ ), при цьому волога, що міститься в повітрі, конденсується, і вода виводиться до збірника конденсату 3. Далі холодне осушене повітря нагрівається в конденсаторі теплового насоса 4 (процес $d-a$ ) і повертається до сушильної камери 1 .

Необхідно відмітити, що теплонасосна сушарка не викидає вологий теплоносій (пару) в оточуюче середовище. Враховуючи, що пара відноситься до парникових газів, то теплонасосна сушарка $є$ екологічно безпечною. 


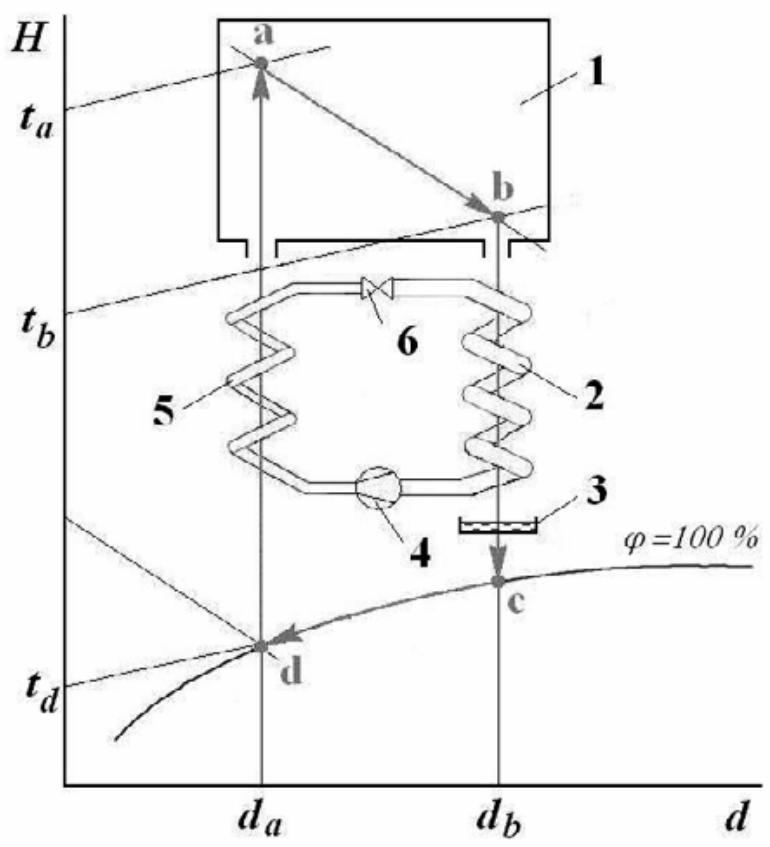

Рис. 1. Процес теплонасосного сушіння в $H-d$ діаграмі:

1 - сушильна камера; 2 - випарник; 3 - збірник конденсату; 4 - компресор; 5 конденсатор; 6 - дросель

Таким чином, волога, що вилучається з матеріалу, не виноситься сушильним агентом в оточуюче середовище, як це має місце в традиційних конвективних сушарках, а конденсується на холодній поверхні випарника теплового насосу і вилучається в скрапленому вигляді. Тобто 3'являється можливість утилізувати теплоту конденсації та повернути іiі в процес сушіння на більш високому температурному рівні, що суттєво впливає на енергоспоживання сушарки.

Так витрати енергії на видалення вологи під час конвективного сушіння, 3 урахуванням втрат теплоти з відпрацьованим теплоносієм і висушеним матеріалом, досягають більш ніж 6000 кДж/кг (в середньому становлять 4000-4500 кДж/кг). Інтеграція теплового насоса в цикл конвективної сушарки дозволяє значно (в 1,5-2 рази) скоротити витрати енергії на вилучення вологи [1].

При сушінні сипких матеріалів оптимальним $\epsilon$ застосування сушарок із псевдозрідженим шаром. Як показують дослідження, доцільно застосовувати сушарку із псевдозрідженим шаром в поєднанні 3 тепловим насосом. На рис. 2 надана схема багатоступінчатої теплонасосної сушильної установки з псевдозрідженим шаром, яка складається з двох незалежних сушарок і двох теплонасосних контурів [2]. 


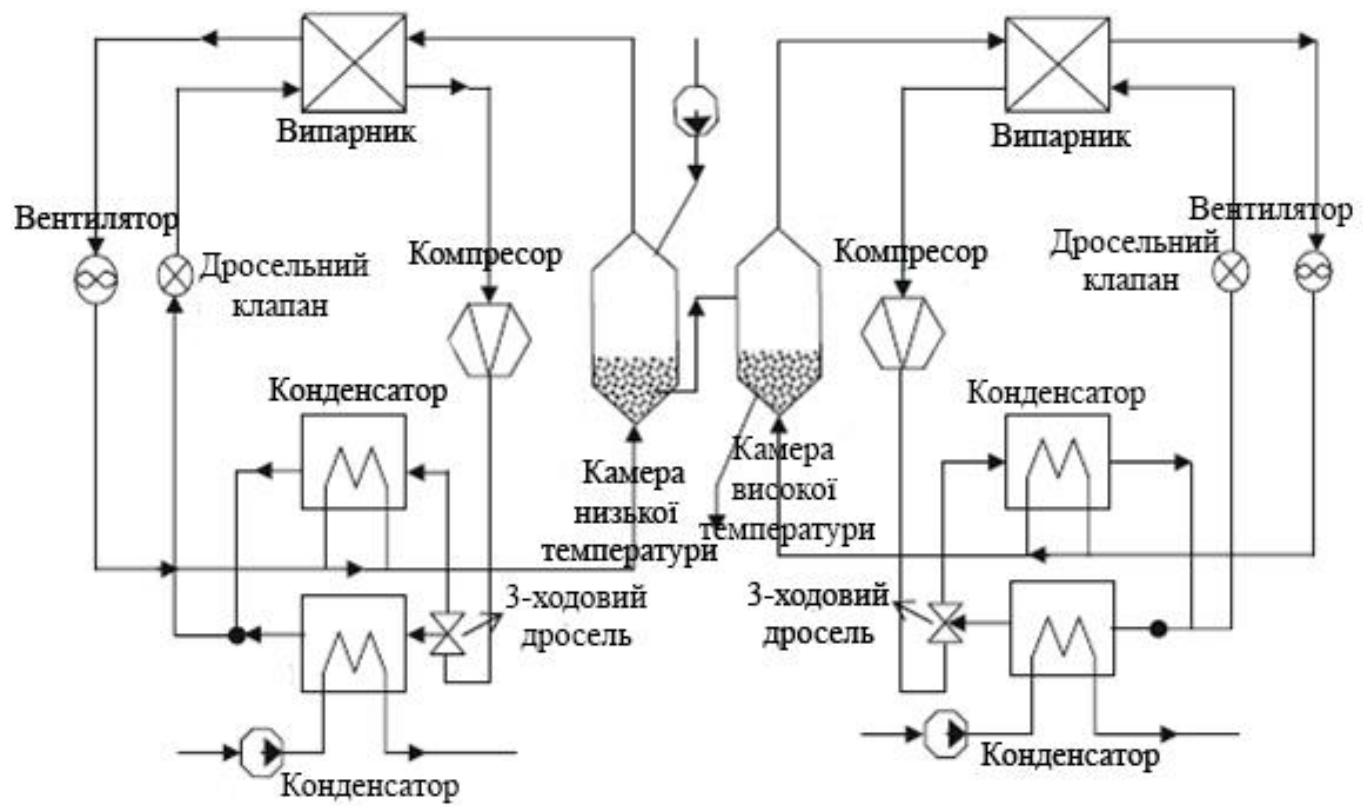

Рис. 2. Схема багатоступінчатої теплонасосної сушильної установки з псевдозрідженим шаром

Для підвищення ефективності роботи теплонасосної сушарки широко застосовується додаткове сонячне нагрівання. На рис. 3 надана схема теплонасосної сушарки з додатковим підігрівом теплоносія [2].

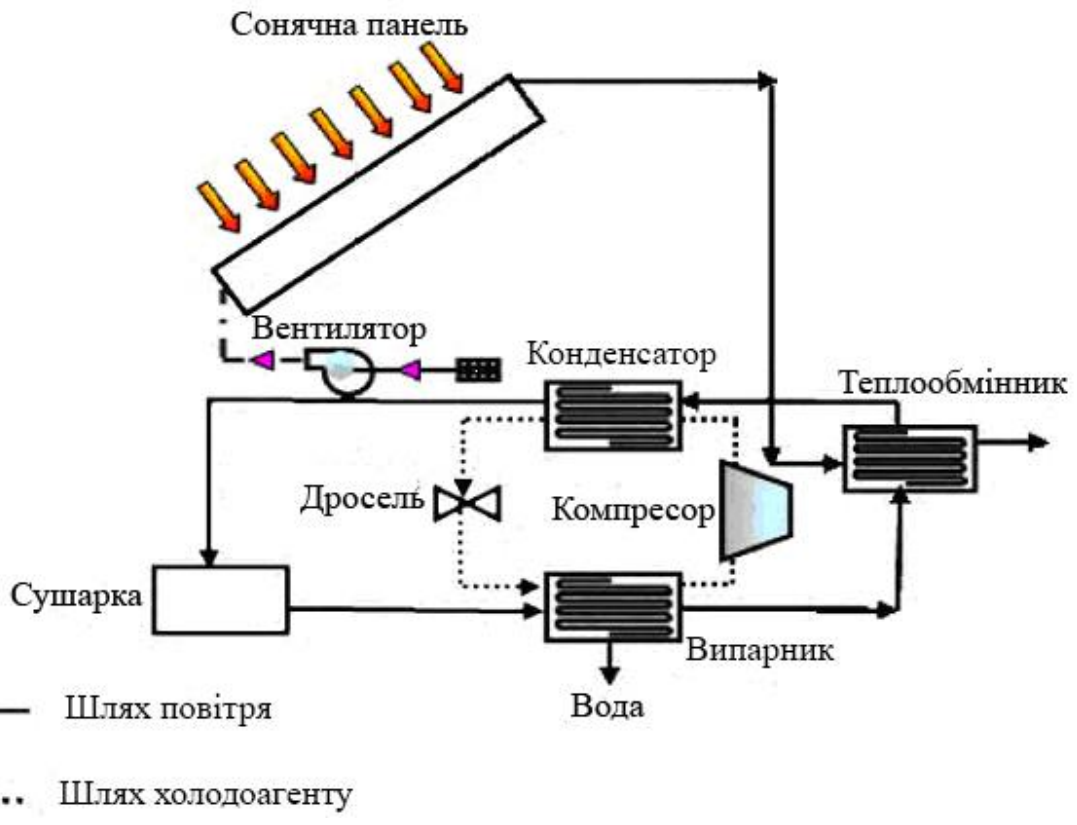

Рис. 3. Схема спрощеної системи теплонасосної сушарки з додатковим сонячним підігрівом 
Повітря, що проходить через численні трубки, в сонячній панелі нагрівається. Цим нагрітим повітрям у теплообміннику підігрівається теплоносій сушильного контуру перед конденсатором для додаткового підживлення.

Також можуть бути використані в сушильних установках теплонасосні системи 3 багатоступінчастим стисненням холодоагенту (рис. 4). Перевагою застосування багатоступінчастого циклу теплового насоса $є$ можливість регулювання вологості сушильного агенту [2].

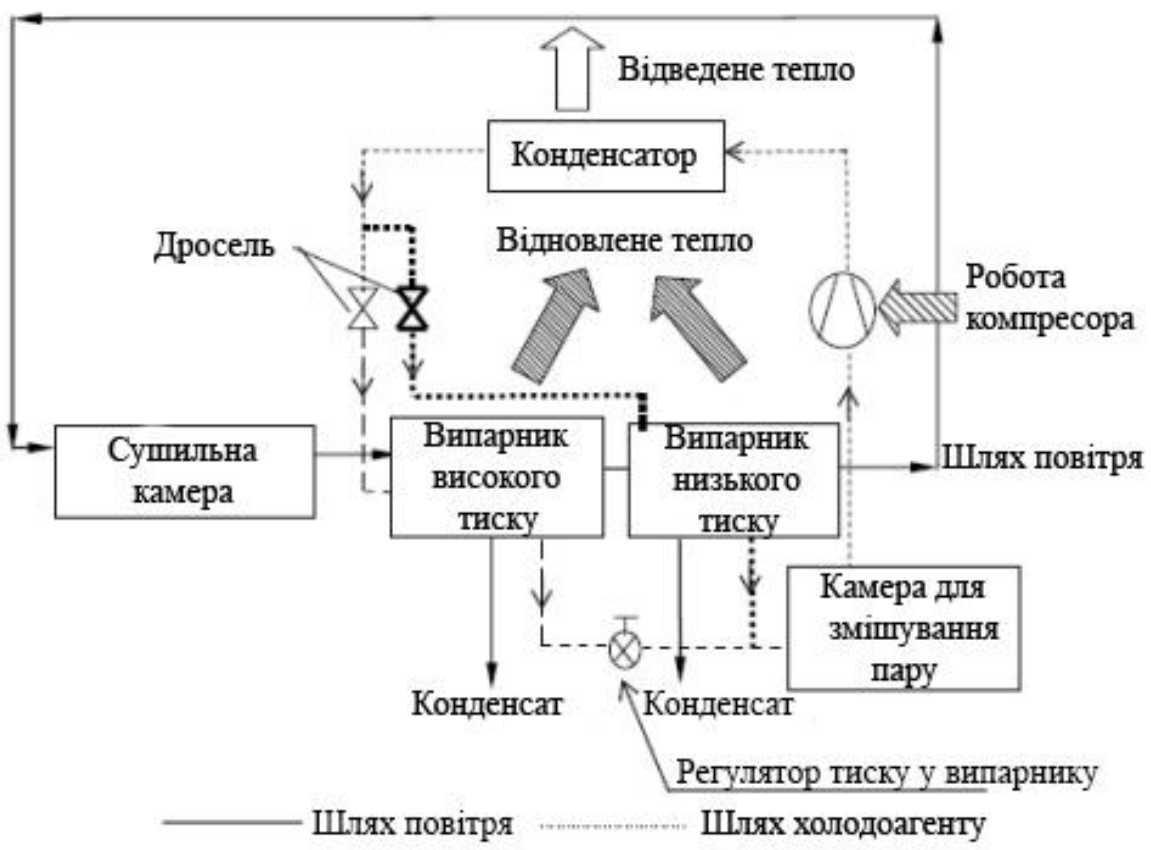

Рис. 4. Двоступінчаста теплонасосна система в поєднанні із сушильною камерою

Як показав аналіз літературних джерел, сушіння ККП матеріалів найбільш доцільно реалізовувати в конвективних сушарках із застосуванням теплових насосів [1]. Але при цьому швидкість сушіння на початковій стадії процесу низька, що приводить до збільшення часу сушіння. Ефективність роботи теплонасосної сушарки може бути підвищена шляхом застосування додаткового нагріву за допомогою інфрачервоних нагрівачів [3].

Додатковий інфрачервоний нагрів приводить до швидкого нагрівання ККП сировини, що значно інтенсифікує видалення вільної вологи на початкових етапах сушіння. Впродовж наступного етапу сушіння, аж до досягнення висушуваним матеріалом необхідного залишкового вологовмісту 8-12\%, застосовується періодичний режим сушіння, який реалізовується комбінованим теплопідводом за допомогою 
теплонасосного агрегату та інфрачервоних випромінювачів, які працюють почергово в осцилюючому режимі. Це дозволяє прискорити процес зневоднення та скоротити час сушіння, а також підвищити якість продукції за рахунок зменшення часу перебування матеріалу в сушильній камері, а, отже, зменшити ймовірність розтріскування керамічної сировини.

На рис. 5 зображена принципова схема сушарки 3 тепловим насосом та інфрачервоними нагрівачами для сушіння керамічної сировини [2].

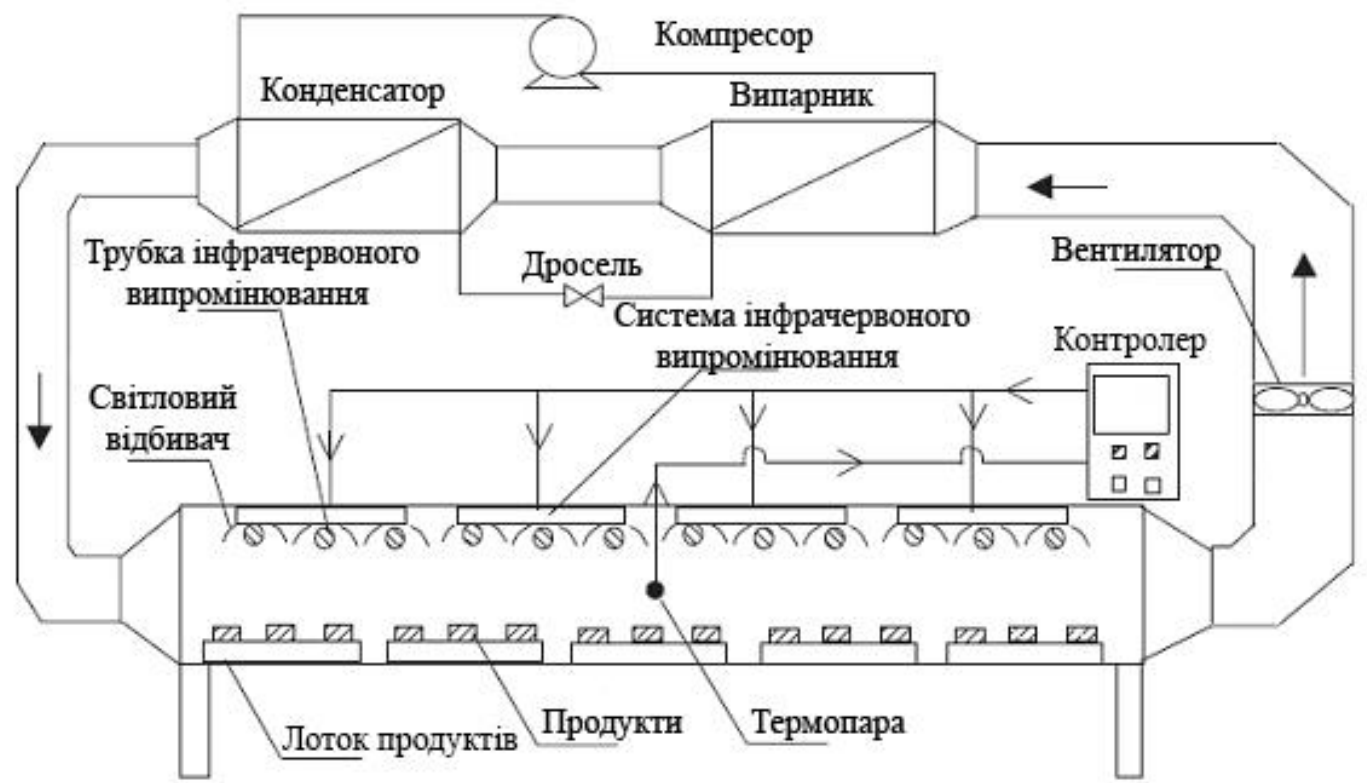

Рис. 5. Принципова схема сушарки з тепловим насосом та інфрачервоними нагрівачами

Інфрачервоний додатковий нагрів дозволяє скоротити час сушіння. Енергія інфрачервоного випромінювання передається від нагрівального елементу до поверхні термолабільного матеріалу без нагріву повітря.

Як джерелом інфрачервоних променів використовують: лампи розжарювання, кварцеві трубчаті випромінювачі, трубчаті електровипромінювачі, керамічні ІЧ випромінювачі, панельні ІЧ випромінювачі, галогенні ІЧ випромінювачі, плівкові ІЧ випромінювачі.

Інфрачервоне сушіння має наступні переваги:

- компактні нагрівачі забезпечують високі показники теплопередачі;

- легкість направляння джерела тепла на сушильну поверхню;

- мала інертність управління процесом; 
- простота конструкції та невисокі капітальні затрати.

При нагріванні виробу інфрачервоними променями відбувається поглинання матеріалом виробу променистої енергії з довжиною хвилі 140-650 нм і наступним переходом ії̈ в теплову енергію. Глибина проникнення інфрачервоного випромінювання в керамічний виріб визначається його складом і структурою, але взагалі незначна 0,05-1 мм. При сушінні виробів інфрачервоними променями враховують те, що фарфоровий виріб поглинає значно більшу кількість променистої енергії, а гіпсовий поглинає їі у кілька разів менше, що може призвести до іï перегріву [4]. При використанні додаткового інфрачервоного випромінювання із застосуванням теплового насосу необхідно забезпечити інтенсивний відбір вологого повітря, так як водяна пара, що утворюється над поверхнею виробів, поглинає значну кількість інфрачервоних променів, знижуючи тим самим ефективність сушіння.

\section{Висновки}

В результаті можливо зробити висновок, що для підвищення енергоефективності сушарок їх необхідно або модернізувати, або створити нові, виходячи із принципів екологічної безпеки та раціонального використання енергоресурсів. Одним із шляхів модернізації $\epsilon$ застосування комбінованих способів теплопідводу 3 використанням теплових насосів.

Проведені дослідження показали, що для сушіння ККП, зокрема керамічних виробів, доцільною $є$ інтеграція теплового насосу в цикл конвективної сушарки. Підвищити ефективність роботи теплонасосної сушарки та оптимізувати режими сушіння можливо шляхом застосування додаткового інфрачервоного нагріву.

\section{Перелік посилань}

1. Дабижа Н.А. Оптимизация режимов теплонасосной сушки коллоидных капиллярнопористых материалов / Н.А. Дабижа // Промышленная теплотехника. - 2007. - Т.29, № 5., C.57-60.

2. Chou S.K. Heat Pump Drying Systems / S.K. Chou, K.J. Choak // Handbook of Industrial Drying, Fourth Edition / CRC Press 2014 - P. 1104-1132.

3. Снежкин Ю.Ф. Эффективность применения тепловых насосов в процессах конвективной сушки / Ю.Ф. Снежкин, Д.М. Чалаев, В.С. Шаврин, Н.А. Дабижа, К.А. Гатилов // Наукові праці ОНАХТ. - Одеса: 2007. - Вип.30. - Т.1. - С.185-189.

4. Домокеев О.Г. Будівельні матеріали // Керамічні матеріали та вироби - 2-е вид., Перероб.і доп. - М. : Вища. . шк, 1989. - 494 с. 